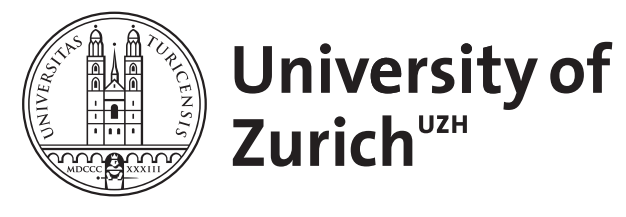

\title{
Is there really an aspectual se in Spanish?
}

\author{
De Benito Moreno, Carlota
}

\begin{abstract}
The goal of this paper is to revisit the so-called aspectual se, frequently cited over the last three decades as a new function of reflexive pronouns in Spanish and other languages, which refers to facultative uses of the reflexive pronoun where it has no effect on the valency or diathesis of the verb. I will focus on four empirical problems that such accounts face when dealing with corpus data: the requirement of a delimited object for transitive verbs, the semantic implications of the aspectual function of the reflexive pronoun, the unacceptability of the reflexive pronoun with some predicates, and the fact that these accounts have ignored a number of predicates that also take this facultative reflexive pronoun. I argue that a larger sample of both contexts and verbs, obtained by exhaustively analyzing corpus data, is necessary to improve our understanding of these uses. Keywords: aspectual se; empirical data; language variation; reflexive constructions; Spanish
\end{abstract}

DOI: https://doi.org/10.1515/flin-2020-2074

Posted at the Zurich Open Repository and Archive, University of Zurich

ZORA URL: https://doi.org/10.5167/uzh-213898

Journal Article

Published Version

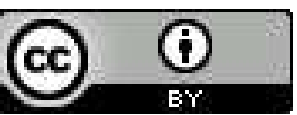

The following work is licensed under a Creative Commons: Attribution 4.0 International (CC BY 4.0) License.

Originally published at:

De Benito Moreno, Carlota (2021). Is there really an aspectual se in Spanish? Folia Linguistica, 55(1):195230.

DOI: https://doi.org/10.1515/flin-2020-2074 


\title{
Carlota de Benito Moreno* \\ Is there really an aspectual se in Spanish?
}

https://doi.org/10.1515/flin-2020-2074

Received April 18, 2019; accepted September 13, 2020; published online January 15, 2021

\begin{abstract}
The goal of this paper is to revisit the so-called aspectual se, frequently cited over the last three decades as a new function of reflexive pronouns in Spanish and other languages, which refers to facultative uses of the reflexive pronoun where it has no effect on the valency or diathesis of the verb. I will focus on four empirical problems that such accounts face when dealing with corpus data: the requirement of a delimited object for transitive verbs, the semantic implications of the aspectual function of the reflexive pronoun, the unacceptability of the reflexive pronoun with some predicates, and the fact that these accounts have ignored a number of predicates that also take this facultative reflexive pronoun. I argue that a larger sample of both contexts and verbs, obtained by exhaustively analyzing corpus data, is necessary to improve our understanding of these uses.
\end{abstract}

Keywords: aspectual se; empirical data; language variation; reflexive constructions; Spanish

\section{Introduction}

There is a huge literature on reflexive constructions, both cross-linguistically and within specific languages and language families. The reason for this wide interest in reflexives is the functional overload that these elements show in many languages, where the reflexive marker (henceforth RM) can not only appear in semantically reflexive constructions but can also act as a reciprocal marker (see, for instance, the studies presented in Nedjalkov [2007]), a middle marker (see, among others, Kemmer [1993]) or even as a passive or impersonal marker (see Siewierska [1984] for a typological account). For a smaller number of languages, an allegedly aspectual function of the RM has also been described (see Cornips and Hulk [1996] for Heerlen Dutch and French, Campanini and Schäfer [2011] for French and Italian), an analysis that has been very successful for some Spanish

*Corresponding author: Carlota de Benito Moreno, UFSP Sprache und Raum/Romanisches Seminar, University of Zurich, Zürichbergstrasse 8, CH-8032 Zurich, Switzerland, E-mail: carlota.debenitomoreno@uzh.ch. https://orcid.org/0000-0001-9112-5471

๖ Open Access. ( 2020 Carlota de Benito Moreno, published by De Gruyter. (G) BY licensed under the Creative Commons Attribution 4.0 International License. 
constructions over the last three decades or so (Basilico 2010; Campanini and Schäfer 2011; De Miguel and Fernández Lagunilla 2000; McCready and Nishida 2008; Nishida 1994; Rigau 1994; Sánchez López 2002; Sanz and Laka 2002; Zagona 1996). In this paper, I challenge these claims for an aspectual se in Spanish by identifying some empirical problems that arise in connection with it. In order to do so, I will use corpus data of spoken Spanish from different varieties of Peninsular Spanish, as compiled in COSER (Fernández-Ordóñez 2005). ${ }^{1}$

The paper is structured as follows. In Section 2, I summarize the main characteristics of the analyses that have identified an aspectual se in Spanish. The data is then briefly described in Section 3. Section 4 focuses on some empirical inadequacies of the aspectual analysis regarding: a) requirements on the DO of transitive predicates that take the RM (Section 4.1), b) the aspectual characteristics and semantic implications of some predicates that take the RM (Section 4.2), and c) those predicates that are claimed not to take the RM (Section 4.3); in Section 4.4, I discuss some predicates omitted from previous accounts. The final section then provides a discussion of the findings and argues for an exhaustive approach to the analysis of these uses.

\section{Aspectual se}

Although a consensus regarding the different functions that the RM might exhibit in Spanish is far from having been reached, some broad functions, such as the reflexive proper, ${ }^{2}$ the reciprocal, the passive and impersonal, and other valencyreducing functions are identified in one way or another in almost all of the many analyses to be found in the literature (Alcina and Blecua 1975; Cartagena 1972; Gómez Torrego 1992; Martín Zorraquino 1979; Otero 2002; Sánchez López 2002; among many others). Similarly, most authors identify a number of uses that do not fit in any of these categories because they are "facultative use[s] and thus the

1 This paper is based on my doctoral thesis (De Benito Moreno 2015). It offers a more synthetic view than the large and exhaustive analysis of all reflexive constructions with no change of valency found in the COSER data which I conducted for my dissertation; instead, it focuses on the empirical problems such an exhaustive analysis of corpus data raises for the aspectual se category. I would like to thank Inés Fernández-Ordóñez for her comments on previous versions of this paper, as well as the anonymous reviewers whose observations contributed to some considerable improvements. Any misconceptions or mistakes are my own. Open access funding was provided by the University of Zurich.

2 By 'reflexive proper' I mean semantically and syntactically reflexive constructions where the subject is coreferential with either the direct or the indirect object, which is represented by a formally reflexive pronoun ( $m e, t e, s e, n o s, o s$ ). 
presence of the [reflexive] clitic does not substantially change the properties of the construction: it neither implies a change in the argument structure [...] nor has consequences for the interpretation of any argument” (Sánchez López 2002: 108, my translation). ${ }^{3}$ In these constructions, the RM may attach both to transitive and intransitive verbs.

While traditional accounts did not go much further than merely noting these uses (especially with intransitive verbs) and considering the RM an ethical dative, they have received a great deal of attention in the last twenty-five years. Perhaps the most prevalent tendency in modern accounts (especially within the generative framework) is to attribute an aspectual function to the RM (Basilico 2010; Campanini and Schäfer 2011; De Miguel and Fernández Lagunilla 2000; McCready and Nishida 2008; Nishida 1994; Rigau 1994; Sánchez López 2002; Sanz and Laka 2002; Zagona 1996, and to some extent MacDonald 2017), although some authors have argued that the presence of the RM in these constructions is (also) related to semantic features of the verbal arguments, such as the agentivity of the subject (Aaron and Torres Cacoullos 2005; Armstrong 2013; De la Mora 2011; Di Tullio 2012; García Fernández 2015; Maldonado 1989, 1999, 2000; Rivas 2011; Torres Cacoullos and Schwenter 2008). In this paper, I will concentrate on the former, the aspectual function. Many of the studies addressing these uses focus either on intransitive or on transitive verbs but since they typically assume that the RM bears the same function with both types of predicates, a joint treatment of the different proposals is justified, as I will do in this paper.

The attribution of an aspectual function, typically related to perfectivity, telicity and/or the culmination of the event, is based on contrasts such as those in (1) and (2), taken from the literature. Examples $(1 \mathrm{a}-\mathrm{b})$ below show that reflexive transitive verbs do not admit bare nouns as direct objects (DOs henceforth), and the contrast in $(1 \mathrm{c}-\mathrm{d})$ is intended to illustrate that even with definite nouns, the DO of a reflexive transitive verb must be a delimited entity. The contrasts in (2) show that only predicative adjectives and adverbial adjuncts describing the state of the subject during the culmination of the event are admitted with reflexive intransitive verbs.

(1) a. Yo (me) comi diez manzanas, y ahora
I REFL.1SG ate.1SG ten apples and now
me duele el estómago.
me.DAT hurts the stomach
'I ate ten apples and now my stomach hurts'
(Nishida 1994)

3 "un uso facultativo, de modo que la presencia del clítico no cambia sustancialmente las propiedades de la construcción: ni implica un cambio en la estructura argumental [...], ni tiene consecuencias para la interpretación de ningún argumento [...]” 
b. Yo (*me) comí manzanas, y ahora

I REFL.1SG ate.1SG apples and now

me duele el estómago.

me.DAT hurts the stomach

'I ate apples and now my stomach hurts'

(Nishida 1994)

c. José y yo ya (nos) sabemos

José and I already REFL.1PL know.1PL

toda la lección.

all the lesson

'José and I already know the whole lesson'

(Nishida 1994)

d. José y yo (*nos) sabemos muy

José and I REFL.1PL know.1PL very

bien el español.

well the Spanish

'José and I can speak Spanish very well'

(Nishida 1994)

(2) a. Juan (*se) murió fusilado.

Juan REFL.3 died.3SG executed

'Juan died executed (by gunshot)'

(De Miguel and Fernández Lagunilla 2000)

b. Juan (se) murió tranquilo.

Juan REFL.3 died.3SG calm

'Juan died calm(ly)'

(De Miguel and Fernández Lagunilla 2000)

c. Juan ( ${ }^{*}$ se) salió difícilmente de la cueva.

Juan REFL.3 went.out.3SG with.difficulty from the cave

'Juan went out of the cave with difficulty'

(De Miguel and Fernández Lagunilla 2000)

d. Juan (se) salió tranquilamente de la fiesta.

Juan REFL.3 went.out.3SG calmly from the party

'Juan left the party calmly'

(De Miguel and Fernández Lagunilla 2000)

While many authors have proposed that the presence of the RM with these verbs is related to the aspectual characteristics of the predicate, specific accounts vary as to which aspectual characteristics are attributed to the reflexive pronoun or verb. Early accounts had already noted that reflexive verbs such as morirse 'to die', 
venirse 'to come', marcharse 'to leave', quedarse 'to stay/remain', caerse 'to fall' and dormirse 'to fall asleep' are perfective, as opposed to their non-reflexive counterparts (Fernández Ramírez 1986). It has also been proposed that what enables the presence of the RM is the telicity of the predicate, this from both a generative perspective (Sanz and Laka 2002) and within the framework of Role and Reference Grammar (Kailuweit 2011). For others, the RM marks the culmination of the event (De Miguel and Fernández Lagunilla 2000; Zagona 1996) or the delimitation of the object (Nishida 1994).

All these proposals share the prediction that only some predicates accept the presence of the RM although exactly which ones varies from author to author. There seems to be some agreement that these predicates are typically accomplishments (Sanz and Laka 2002) although some authors also add delimited states to the list (Nishida 1994), while others exclude predicates where the culmination of the event is not followed by a result state (De Miguel and Fernández Lagunilla 2000). Another point of divergence is that different theoretical accounts may attribute adverbial functions to the reflexive pronoun (De Miguel and Fernández Lagunilla 2000; Zagona 1996) or categorize it as a low applicative (Teomiro 2013) or a light verb (Basilico 2010).

While formal accounts of the so-called aspectual se show some differences in the specific details of the analysis, they also share some core characteristics, four of the most relevant for our purposes being the following:

1. Aspectual se is legitimized by the aspectual class of the sentence in which it appears. Different authors identify different specific aspectual restrictions that affect aspectual se, but these are always related to telicity, perfectivity, delimitation or culmination of the event. In this sense, it is commonly agreed that the event marked by the RM must have an endpoint at which the action is complete.

2. These aspectual restrictions have consequences in the formal properties of DOs in reflexive transitive verbs, which cannot be bare plurals or mass nouns (Nishida 1994; Sánchez López 2002; Zagona 1996), see (1b) above. ${ }^{4}$

3. As noted above, aspectual se cannot appear with all predicates. Attempts to identify the aspectual feature that allows its presence are not only intended to explain which predicates admit the RM, but also which predicates reject it.

4. It is unclear whether semantic restrictions on the role of the subject also play a role in the presence of the RM. For some authors, a subject's volitionality or control is higher in reflexive intransitive verbs than in their unmarked

4 The semantic description of these DOs, however, is also a matter of discussion - different accounts require them to be definite (Sánchez López 2002), specific (Rigau 1994) or “quantitatively delimited" (Nishida 1994: 428). 
counterparts, as shown with estar(se) 'to be' (Sánchez López 2002), or the subject needs to be an agent in the case of reflexive transitive verbs (Sanz and Laka 2002). For other authors, the subject need not comply with any restrictions and might also be an experiencer (De Miguel and Fernández Lagunilla 2000). ${ }^{5}$ While recent studies analyzing some of these verbs from a variationist approach have defended the relevance of semantic parameters related to the role of the agent, such as subjectivity and counter-expectation, authors defending the aspectual se interpretation consider aspectual restrictions of the predicate more relevant than other possible semantic considerations:

Taking into account all the cases where the clitic is legitimized, we conclude that the only characteristic of the subject that is relevant to the analysis of these constructions is the fact that the clitic, which has person and number features, must agree with it. Regarding a potential thematic or semantic relationship between the subject of the event and the clitic, which has been postulated in some previous proposals, we believe it does not exist, because the semantic and thematic characteristics of the subject are irrelevant to the presence of the clitic (Sanz and Laka 2002: 322, my translation). ${ }^{6}$

In summary, aspectual accounts of reflexive verbs with no change of valency in Spanish propose that the RM has a clearly-defined aspectual function and that its distribution is subject to clear-cut restrictions depending on the aspectual characteristics of the predicate. As will be shown, these aspectual accounts tend to focus on a small subset of verbs that optionally admit the RM without changing their argument structure or the interpretation of an argument in Spanish, and hence fall under Sánchez López’s (2002) definition, given above. This is probably due to the fact that, from a methodological perspective, aspectual accounts of the RM are generally built on introspective judgements, typically those of the authors themselves. ${ }^{7}$ While introspection has proved to be a useful technique in the

5 The characteristics of the subject are said to play a fundamental role in the presence of the reflexive pronoun with transitive verbs in accounts that do not advocate the aspectual se analysis, such as highlighting the agent's involvement (Maldonado 2000) or the requirement that the subject must be an exceptional agent (De la Mora 2011; Di Tullio 2012). This is not to say that such analyses reject an effect of aspectual parameters, but that their interpretation of the main function of the RM is not based on aspectual factors.

6 "Considerando todos los casos de legitimación del clítico, concluimos que la única propiedad del sujeto relevante para el análisis de estas construcciones es el hecho de que el clítico, que tiene rasgos de persona y número, ha de concordar con él. Respecto a la posible relación temática o semántica entre el sujeto del evento y el clítico, postulada por algunas propuestas anteriores, creemos que no hay tal, porque las características semánticas y temáticas del sujeto son irrelevantes para la presencia del clítico."

7 An exception to this is Nishida (1994), where a questionnaire was used to test the acceptability judgements of native Spanish speakers from different countries. 
description of systematic grammatical processes, I will argue that this is not so for the description of highly lexically-dependent phenomena, such as appears to be the case with the addition of a facultative RM.

Using introspection as a basis for analysis has led to accounts of aspectual se relying on "clear examples" (Itkonen 2005; Willems 2012) of a few salient verbs. Such clear examples make it possible to propose a clear-cut function for the RM. This method illustrates the fact that humans are better at deducing the general from the particular than the converse case (Nisbett and Borgida 1975). Nevertheless, clear examples can be misleading, because "[t]he human mind does not deal well with nonevents” (Kahneman 2011: 200). Accordingly, we tend to jump to conclusions as soon as we have made sense out of the available evidence, becoming blind to the fact that there might be an absence of important evidence. Moreover, the human mind also has trouble assessing the adequacy of small samples (Tversky and Kahneman 1971) and can easily infer an extreme behavior of a population based on very few examples (Nisbett and Borgida 1975). While these cognitive biases are of little importance when addressing a homogeneous population that shows systematic behavior with little variability, they can have a significant effect on the analysis of more heterogeneous situations.

In this paper, I argue that the strong reliance on a small number of examples, most of which show clear-cut contrasts, has resulted in a skewed sample of the data analyzed, and that as a consequence a number of contexts have been overlooked, some of which might indeed be the most frequent ones in actual speech. This is clearly seen in the COSER data with the verb ir(se) 'to go', which is commonly cited in works on aspectual se to show that the presence of the RM might affect the aspectual structure of the predicate (De Miguel and Fernández Lagunilla 2000; Sánchez López 2002; see also Section 4.2.1). Examples such as (3) below, in which the presence of the RM correlates with the presence of a source complement and the verb takes the meaning 'to leave', are typically adduced to support this hypothesis. Figure 1 shows the relative frequency of ir (with no RM) versus irse (with RM) in the COSER data in six different contexts: with goal phrases with locative adverbs, preposition $a$ 'to' and preposition para 'for', with no locative phrases, with goal phrases with preposition por 'through', and with source complements with preposition de 'from, out of'. These data 1) confirm that the RM is most frequent in relative terms with source phrases (and must appear if de means 'out of', see Section 4.2.1), 2) show that these are the least frequent contexts overall, and 3) that irse is much more frequent in absolute terms when neither a goal complement nor a locative phrase is present, and where the nuance of leaving need not be present (see Section 4.2.1); that is, the corpus data confirm that the contrast in (3) is correct and show that such a contrast represents an extreme behavior found in only a small subset of examples. 


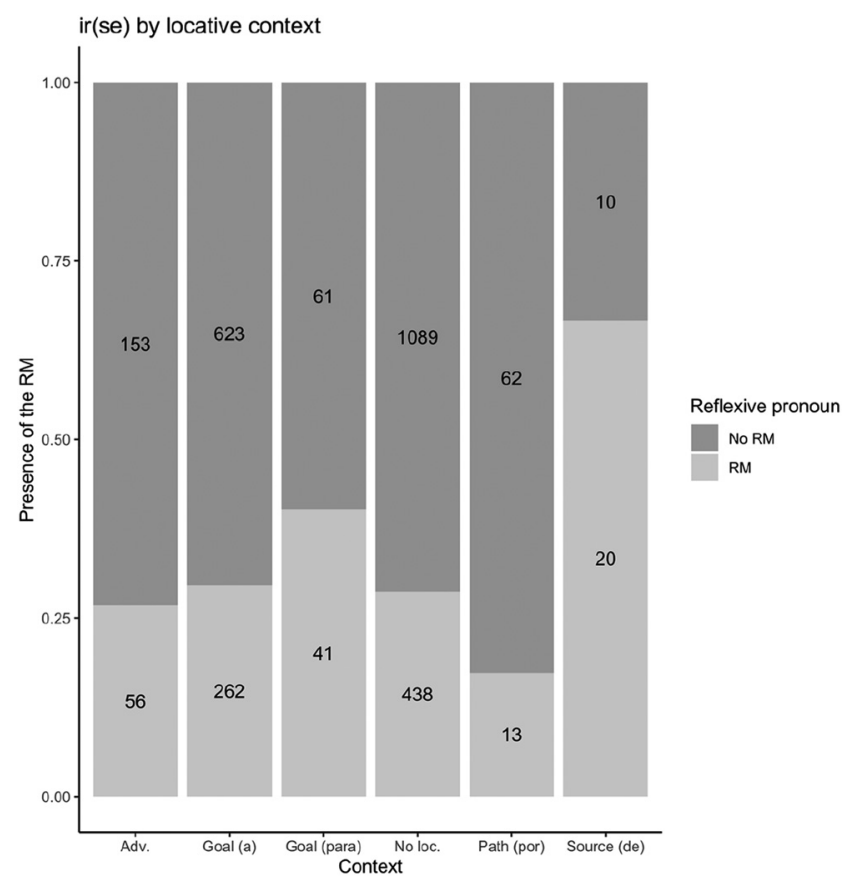

Figure 1: Frequency of the RM with ir by locative complement in the COSER data.

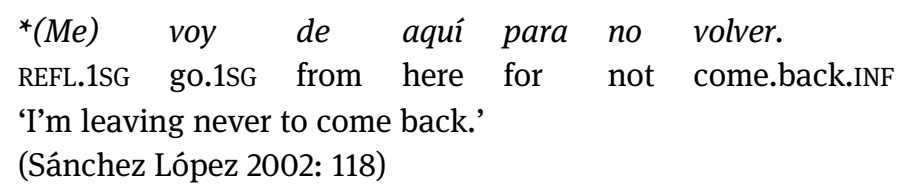

The aim of the current study is to show the limitations of comprehensive accounts of reflexive verbs with no change of valency in Spanish based on introspective judgements and intuitively selected examples, in that they leave large amounts of evidence unaccounted for. When a comprehensive corpus analysis is performed, the distribution of the RM seems not to be determined by any strict syntactic and semantic constraints, but to be the product of a number of analogical processes related to several characteristics of the verb (often not related to its aspect) as proposed in De Benito Moreno (2015, in revision). For reasons of space, I will focus on aspectual accounts since they are the ones that most consistently propose a comprehensive account of these verbs. Because I believe that corpus-based research is crucial in addressing such empirical inadequacies, this paper is meant as a critique of the method and not of the theoretical perspective adopted in such studies; as such, the criticism is equally applicable to other comprehensive 
accounts of these reflexive verbs that rely on introspection, such as those of Maldonado (1999, 2000), in which a cognitive framework is adopted.

\section{Data and methodology}

This study, contrary to virtually all those that have thus far argued for an aspectual nature of se, is based on corpus data. In this sense, it follows more recent work that has adopted a variationist perspective in the study of these forms (Aaron 2003, 2004; Aaron and Torres Cacoullos 2005; De la Mora 2011; Merino Hernández 2019; Rivas 2011; Torres Cacoullos and Schwenter 2008). Most of these studies are 'agnostic' towards the aspectual interpretation of the RM or in fact lean towards a subjective reading, often related to Maldonado's (1999, 2000) cognitive proposal. Although I believe that variationist analyses of this kind are very much suited to the study of reflexive verbs with no change of valency since they exhaustively consider the contexts in which these verbs appear, they also show effects of the introspective bias noted above, in that they focus on very few verbs, virtually all of which have been extensively discussed in aspectual accounts of the RM. ${ }^{8}$

I have analyzed 139 interviews from the COSER corpus (Fernández-Ordóñez 2005). This corpus consists of semi-directed, in-situ interviews of around $64 \mathrm{~min}$ with non-mobile, older rural speakers (both male and female) from various villages in Spain. The mean age of the speakers in this ongoing corpus is 73.4 years. The interviews were conducted in all provinces of Peninsular Spain except Catalonia (because interviews had yet to take place at the time); Galicia and Asturias were also omitted since it is known that reflexive pronouns in their regional languages, Galician and Asturian, as well as the Spanish spoken in these areas, are less productive and appear in fewer types of reflexive constructions (Cidrás Escáneo 1991; D’Andrés 1994; De Benito Moreno 2015, among others). The locations of the different villages included are shown in Figure 2.

The examples were collected by manually extracting all instances of the relevant verbs from the transcriptions. For some extremely frequent verbs, such as ir(se) ‘to go' or saber(se) ‘to know', instances were exhaustively collected only in a subset of the total interviews. This subset includes 54 interviews and has at least one interview per province (De Benito Moreno 2015); the subset is referred to as 'subcorpus E' henceforth.

8 These verbs are salir(se) 'to go out', ir(se) 'to go', subir(se)/bajar(se) 'to go up/down', comer(se) 'to eat', beber(se) 'to drink', tomar(se) 'to eat, to drink', tragar(se) 'to swallow', morir(se) 'to die'. To the best of my knowledge, only De Benito Moreno (2015, in revision) has attempted an exhaustive study of the verbs that accept the facultative use of the RM based on corpus data. 


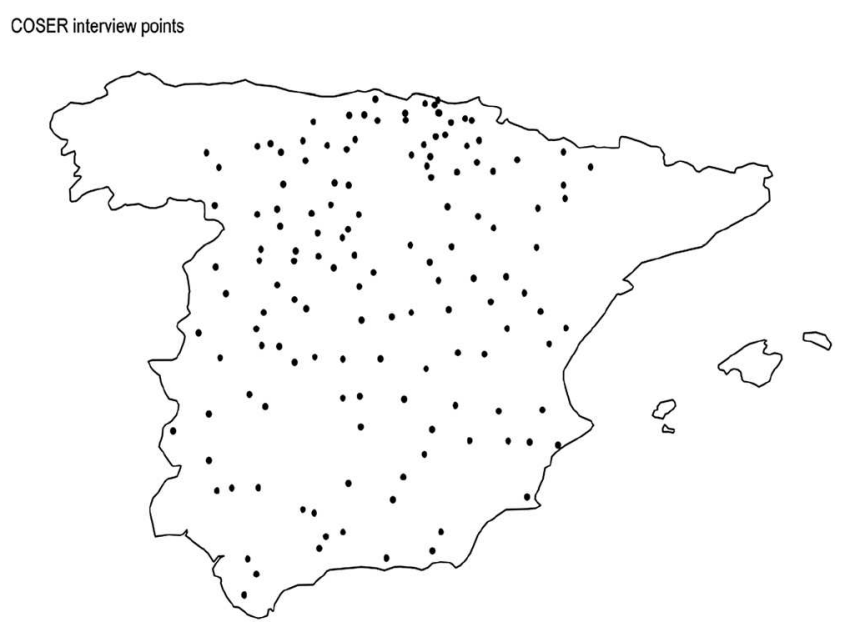

Figure 2: Geographical distribution of the COSER interviews used.

Since the COSER corpus collects spoken and substandard language, the spelling of the examples does not always conform to the orthography of Standard Spanish and shows some of the variable pronunciation features of different speakers. When suggesting that an example is unacceptable, I will avoid the use of the asterisk $\left(^{\star}\right)$ and instead use double question marks (??) since my experience with corpus data advises me against generalizing my own judgements to other varieties, or even to my own.

Since the goal of the paper is not to propose a new analysis of these reflexive verbs (for this see De Benito Moreno 2015, in revision), the quantitative data are only intended to confirm or disprove the existence of the contrasts proposed in the literature. Thus, no inferential statistics is used.

\section{Four problems with current accounts of the so-called aspectual se}

In this section I discuss some of the empirical inadequacies that the exhaustive analysis of corpus data show when confronted with some of the most important generalizations that aspectual accounts propose. I will discuss the requirements on the delimitation of the DO of reflexive transitive verbs (Section 4.1), the semantic implications of the aspectual function of the RM in the meaning of the verb (Section 4.2), and the rejection of the RM by predicates that do not 
conform to this aspectual function (Section 4.3). In Section 4.4, I will discuss some of the evidence that these accounts leave out regarding verbs that do admit the RM but which have not been discussed in previous accounts.

\subsection{Reflexive transitive verbs and the delimitation of the object}

One of the most pervasive features that has been used to prove that the distribution of the RM is determined by aspectual constraints affects the nature of the DO of reflexive transitive verbs. Most authors agree that this argument cannot be encoded by a bare noun and that it must be "quantitatively delimited" when the RM is present (Nishida 1994: 428; see also De Miguel and Fernández Lagunilla 2000; MacDonald 2017; Sanz and Laka 2002). In this section, I will show that this restriction is limited to a small number of reflexive transitive verbs.

While most work on aspectual se relies on the distinction between delimited and non-delimited objects, this is not always clearly explained. I will follow Nishida's (1994) definitions here because they are the most detailed ones. For this author, "[nominals] compatible with $\mathrm{SE}_{\mathrm{q}}$ [aspectual se] refer to entities that are quantitatively delimited, whereas those not compatible with $\mathrm{SE}_{\mathrm{q}}$ refer to entities that do not have a clear upper bound" (Nishida 1994: 431). Accordingly, she claims that mass terms and bare plurals are never quantitatively delimited. On the other hand, count nouns and terms of measurement can indeed be quantitatively delimited but they are not always so, and this depends on the interpretation of the sentence. In order to operationalize the distinction, I will give priority to the formal criterion since subtle semantic notions are difficult to discern and may be affected by the theoretical preconceptions of the investigator; that is, I have classified the following as non-delimited DOs: 1) mass nouns; 2) bare plurals; 3) nominals quantified with the adverbs más 'more', menos 'less', mucho(s) 'much/many' and poco(s) 'little/few' since these have no inherent limit; 4) null pronouns and partitive objects; and 5) sentential objects, which "cannot measure the event" (Sanz and Laka 2002: 321, my translation). ${ }^{9}$ On the other hand, I have classified count nouns and nominal expressions with delimited measure terms as delimited DOs. That is, it must be borne in mind that formally non-delimited objects are always non-delimited semantically, while formally delimited objects are typically delimited semantically although not always. In what follows, I will analyze the delimitation of the object in my data for several classes of verbs which have been considered instances of aspectual se, such as consumption verbs (Section 4.1.1),

9 “[...] un complemento oracional [...] no puede medir el evento". 
verbs of spending time (Section 4.1.2), cognition verbs (Section 4.1.3) and perception verbs (Section 4.1.4).

\subsubsection{Consumption verbs}

Consumption verbs such as comer 'to eat', beber 'to drink' and tomar 'to have, take' have been considered paradigmatic examples of verbs accepting aspectual se (Campanini and Schäfer 2011; De la Mora 2011; MacDonald 2017; Rivas 2011; Zagona 1996) and are regularly used to argue that aspectual se needs delimited objects and hence cannot appear with bare nouns (see (4) and (1a-b) above). It was only recently that examples such as (5) were noticed in the literature.

(4) Juan *(se) comió paella.

Juan REFL.3 ate.3SG paella

'Juan ate paella.'

(Sánchez López 2002: 110)

(5) Socrates se tomó veneno.

Socrates REFL.3 took.3SG poison

'Socrates took poison.'

(Romero and Teomiro 2012: 239)

I will focus on comer(se), beber(se) and tomar(se) since they are the most frequent consumption verbs in the corpus. The COSER data confirm that non-delimited objects are strongly disprefered with verbs such as comerse and beberse (see Tables 1 and 2 respectively), but not with tomarse (see Table 3 ). While the presence of the RM in (6a) with comer might be facilitated by the list reading of the object, tomarse is perfectly acceptable with bare count DOs (6b). These data, then, corroborate De la Mora's (2011) and Riva's (2011) findings - both of them variationist accounts - that the need of a delimited object for the RM to appear with these verbs is not an absolute requirement although it is clearly relevant to understanding the distribution of the RM with at least some of these verbs.

Table 1: Frequency of the RM with comer 'to eat' in terms of the characteristics of the DO (subcorpus E).

\begin{tabular}{lrr}
\hline & Delimited DO & Non-delimited DO \\
\hline Comer & $210(61.9 \%)$ & $97(99 \%)$ \\
Comerse & $129(38.1 \%)$ & $1(1 \%)$ \\
Total & $339(100 \%)$ & $98(100 \%)$ \\
\hline
\end{tabular}


Table 2: Frequency of the RM with beber 'to drink' in terms of the characteristics of the DO.

\begin{tabular}{lrr}
\hline & Delimited DO & Non-delimited DO \\
\hline Beber & $40(68 \%)$ & $43(100 \%)$ \\
Beberse & $19(32 \%)$ & $0(0 \%)$ \\
Total & $59(100 \%)$ & $43(100 \%)$ \\
\hline
\end{tabular}

Table 3: Frequency of the RM with tomar 'to have, to take' in terms of the characteristics of the DO (subcorpus E).

\begin{tabular}{lrr}
\hline & Delimited DO & Non-delimited DO \\
\hline Tomar & $26(49 \%)$ & $18(86 \%)$ \\
Tomarse & $27(51 \%)$ & $3(14 \%)$ \\
Total & $53(100 \%)$ & $21(100 \%)$ \\
\hline
\end{tabular}

(6) a. Porque se lucraban de yerba, inclusive lo because REFL.3 benefited.3PL from grass included it.ACC comian $y$ otras cosas que buscan por ellas, ate.3pl and other things that search.3PL for they gusanos $y$ piedras $y, y \quad$ cosas que se worms and stones and and things that REFL.3 comían.

ate.3PL

'Because they [the chicken] benefited from the grass, they even ate it, as other things they find by themselves, worms, stones and things they used to eat.' (Burgos, COSER 922)

b. Se ha tomado leche cruda. REFL.3 have.1SG taken milk raw 'He’s had raw milk.' (Burgos, COSER 959)

\subsubsection{Verbs of spending time}

According to Nishida (1994), sequences like pasarse un día entero 'to spend a whole day' also contain verbs of consumption, but unlike comer, beber or tomar, which take a 'spatial' object, these verbs take a temporal object. My data document three 
different verbs with variable presence of the RM in this category: llevar(se) 'to take', echar(se) 'to throw out', and pasar(se) 'to spend'. Llevar(se) and echar(se) were only retrieved from subcorpus $\mathrm{E}$.

Although Nishida (1994) includes them in her account, these verbs hardly fit within the prototype described in the literature, or with consumption verbs: 1 ) they are not accomplishments; rather, they are activities that semantically resemble states such as estar 'to be'; 2) their subjects are not agents, but experiencers; 3) the delimitation of the DO is not associated with the presence of the RM as shown in Table 4. The reflexive counterpart of these verbs admits non-delimited DOs (see [7]), although these are globally infrequent, both with and without the RM.

$\begin{array}{llll}\text { Pasarnos } & \text { noches en la cuadra. } \\ \text { pass.INF-REFL.1PL } & \text { nights in the stable }\end{array}$

'We used to spend nights in the stable (with the pigs).'

(Burgos, COSER 934)

\subsubsection{Cognition verbs}

The fact that cognition verbs such as saber 'to know', which is a stative verb, accept the RM is an apparent counterexample to the proposals that claim that aspectual se only attaches to accomplishments. For this reason some authors, like Zagona (1996) and Sanz and Laka (2002), have argued that saber is not always stative (for a more cautious view, see Maldonado 2000). Accordingly, the contrast in (8) is used to argue that (8a) is a quasi-state (Zagona 1996) or an accomplishment (Sanz and Laka 2002) because it has an incremental theme that may delimit the event, while (8b) is a state. However, (8a) fails some of the classic tests that distinguish states from accomplishments (Dowty 1979): it rejects the imperative and progressive tenses, see (9). ${ }^{10}$ At any rate, the contrast in (8) is accepted in most of these studies as proof of the delimitation of the DO being a crucial requirement for aspectual se

Table 4: Frequency of the RM with transitive verbs with a temporal DO (echar, llevar, pasar) in terms of the delimitation of the DO.

\begin{tabular}{lrr}
\hline & Delimited DO & Non-delimited DO \\
\hline No RM & $135(87.1 \%)$ & $7(58.3 \%)$ \\
RM & $20(12.9 \%)$ & $5(41.7 \%)$ \\
Total & $155(100 \%)$ & $12(100 \%)$ \\
\hline
\end{tabular}

10 See also MacDonald (2017), who argues convincingly that stative verbs with se remain stative. 
since those authors agree in considering la lección 'the lesson' as an incremental and delimited object as opposed to clausal objects (see also De Miguel and Fernández Lagunilla 2000; Nishida 1994); that is, studies on aspectual se have claimed that the RM is not compatible with sentential objects because these are non-delimited (i.e. non-incremental) objects (Sanz and Laka 2002).

(8) a. Pedro se sabe la lección.

Pedro REFL.3 knows the lesson

'Pedro knows the lesson.'

(Sanz and Laka 2002: 320)

b. ${ }^{*}$ Pedro se sabe que Luis llegará mañana.

Pedro REFL.3 knows that Luis arrive.3SG.FUT tomorrow

'Pedro knows that Luis will arrive tomorrow'

(Sanz and Laka 2002: 320)

(9) a. ??jSábe-te la lección, Pedro!

know.IMP-REFL.2SG the lesson Pedro

'Know the lesson, Pedro!'

b. ??Pedro está sabiéndose la lección.

Pedro is knowing the lesson

'lit. Pedro is knowing the lesson.'

The COSER data show that this claim is too strict and that saberse can appear with non-incremental DOs, be they pronouns referring to someone's nickname (10a) or clausal objects (10b). All these examples serve to challenge Nishida's (1994: 441) claim that "[with non-dynamic verb complexes] the part structure of the entity denoted by the direct object argument is also reflected in the internal structure of the state denoted by the whole verb complex". Because saberse was rather infrequent compared with saber (8/1457, i.e. $0.5 \%$ in subcorpus E), statistics on the frequency of each context are of little use here.

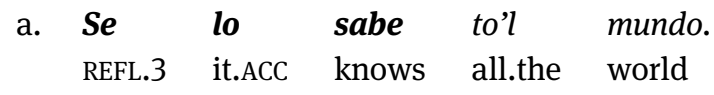

'They all know it [his nickname], everybody.'

(Albacete, COSER 214)

b. iQué me sé yo que de ande

what REFL.1SG know.1SG I that of where

eran, aquellos!

were.3PL those

'What do I know about where those people came from?'

(Zaragoza, COSER 4719) 
Moreover, looking at corpus data, it is clear that restricting the examples to saber(se), as most researchers have done, results in a rather reduced picture of the situation (especially since it takes the RM so infrequently!). There are a number of transitive cognition verbs that can also take the RM and do not seem to show any restriction regarding the delimitation of the object as shown by the frequent examples with sentential objects. In (11), I provide examples of some of the most frequently reflexive cognition transitive verbs: recordarse 'to remember', suponerse 'to supose', imaginarse 'to imagine' and creerse 'to believe'. 11

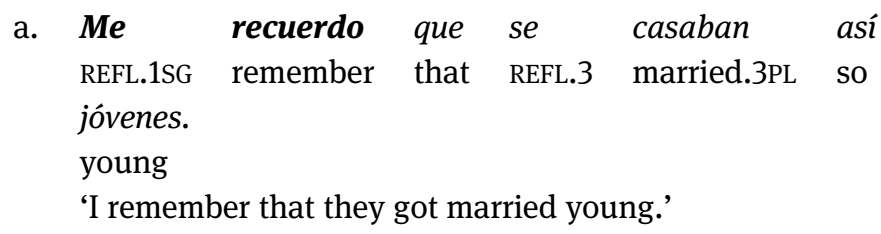

b. Supón-te que la finca es esta. suppose-REFL.2SG that the ranch is this

'Suppose that the ranch is this one.'

(La Coruña, COSER 2403)
c. Tú imagína-te que estân unos recién casaos you imagine-REFL.2SG that are.3PL some recent married con los padres en casa... with the parents in house

'Imagine that a recently-married couple is at home with their parents...' (Burgos, COSER 934)

d. Porque me creo que llevo algo en because REFL.1SG believe.1SG that carry.1SG something in el bolso y luego no llevo na. the purse and then not carry.1sG nothing 'Because I think I have some money in my purse and then I find out I don't.'

(Jaén, COSER 2314)

11 The acceptability of clausal objects with these verbs also contradicts Rigau's (1994) analysis for Catalan, according to which the RM absorbs the accusative case assigned by verbs that select propositional objects (such as lamentar 'to be sorry about' or recordar 'to remember'), triggering the appearance of a preposition de before the clause, that is, producing an antipassive alternation. 
Creer(se) 'to believe', which is explicitly considered by Nishida (1994) and MacDonald (2017) as an example of aspectual se requiring a delimited object, provided enough examples to perform a quantitative analysis on the delimitation of the DO. Table 5 shows that non-delimited DOs - including sentential DOs - are extremely common with both versions of the verb, greatly outnumbering delimited DOs. ${ }^{12}$

\subsubsection{Perception verbs}

Perception verbs such as ver(se) 'to see' have also been mentioned in several studies on aspectual se (De Miguel and Fernández Lagunilla 2000; Nishida 1994; Sanz and Laka 2002). For Sanz and Laka (2002), the contrast in (12) is explained by the fact that in (12a) the subject is an agent, a requirement of every accomplishment. De Miguel and Fernández Lagunilla (2000) reject this analysis and believe that the contrast is explained by the fact that in (12a) the event implies an end result state and se focuses on its culmination. In these contexts, ver(se) has been likened to a consumption verb, similar to leer(se) un libro 'to read a book' or comer(se) una manzana 'to eat an apple' (Campanini and Schäfer 2011; Zagona 1996). Once again, and similarly in the case of cognition verbs, the contrast is said to be ultimately based on the distinction between quantitatively delimited and non-delimited objects (Nishida 1994; Sanz and Laka 2002).

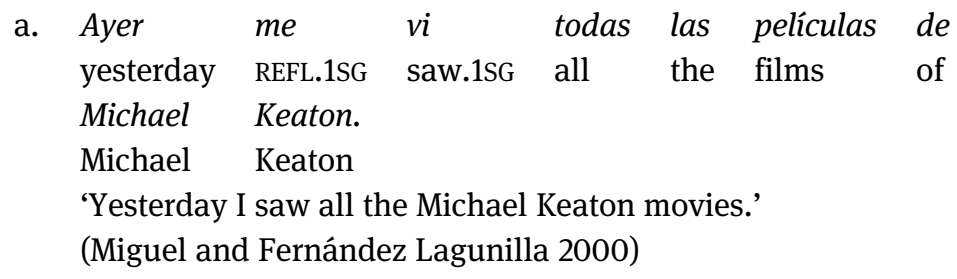

Table 5: Frequency of the RM with creer 'to believe' in terms of the characteristics of the DO.

\begin{tabular}{lrr}
\hline & Delimited DO & Non-delimited DO \\
\hline Creer & $23(29 \%)$ & $198(61.7 \%)$ \\
Creerse & $56(71 \%)$ & $123(38.3 \%)$ \\
Total & $79(100 \%)$ & $321(100 \%)$ \\
\hline
\end{tabular}

12 In fact, the presence of the RM with creer 'to believe' seems to be related to the truth of the belief, a notion which can be related to subjectivity (Anvari et al. 2019; De Benito Moreno 2015). 
b. He salido al jardin y $\left({ }^{*} m e\right)$ he have.1SG gone.out to.the garden and REFL.1SG have.1SG visto a tres niños que salian corriendo. seen to three children that went.out.3PL running 'I have gone out into the garden and I have seen three children who started running.'

(Miguel and Fernández Lagunilla 2000)

No examples similar to those in (12a), i.e. with incremental themes, are documented in my data as might be expected given the topics of the interviews. However, they document a number of clear counter-examples similar to (12b), where the object cannot be understood as an incremental theme, such as (13).

$\begin{array}{lllllllll}Y & \text { llego } & \text { yo } & \text { alli } & y & \text { me } & \text { veo } & a & \text { la } \\ \text { and } & \text { arrive.1SG } & \text { I } & \text { there } & \text { and } & \text { REFL.1SG } & \text { see.1SG to the } \\ \text { señora } & \text { en } & \text { la } & \text { cama. } & & & & & \\ \text { lady } & \text { in } & \text { the } & \text { bed } & & & & & \end{array}$

'So, I arrive there and I see the lady in the bed.'

(Guadalajara, COSER 1921)

De Miguel and Fernández Lagunilla (2000) believe that examples such as (14) are not instances of aspectual se but of a beneficiary clitic, based on the pragmatic contrast between novio 'boyfriend' and profesor 'teacher'. Note, however, that the COSER examples cannot be seen as having beneficiary clitics since the subject is not affected by the event (see [13]), which seems to be the criterion followed by these authors for excluding profesor 'teacher' in (14b). ${ }^{13}$

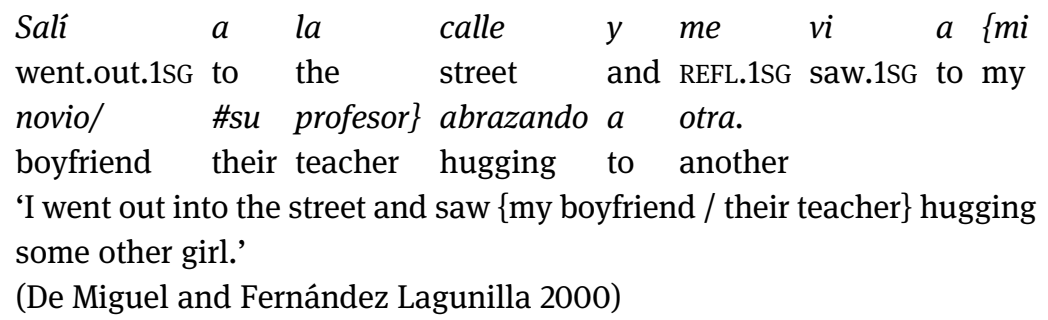

13 In their account, De Miguel and Fernández Lagunilla (2000) do not clarify what is meant by a beneficiary clitic, but it is worth mentioning that the RM is not referential in any of these cases and can never be reinforced by a referential PP such as a si mismo 'oneself' as might be expected if they were referential pronouns in semantically and syntactically reflexive constructions (see Campanini and Schäfer [2011] for a similar argumentation). 


\subsubsection{Summary}

To sum up, the COSER data confirm some of the contrasts on which aspectual accounts have relied especially for the consumption verbs comer 'to eat' and beber 'to drink' but not for the consumption verb tomar 'to take', for verbs of spending time, cognition verbs or perception verbs, all of which have been used in aspectual accounts of the RM. These data show that, by focusing on only a small number of examples, much evidence has been disregarded in previous studies; in addition, the evidence casts doubt on the applicability of the incremental theme restriction to many of the verbs mentioned in those accounts.

\subsection{Semantic implications of aspectual se: perfectivity, telicity and culmination of the event}

Work on aspectual se typically considers this particle to be a secondary marker of some classes of predicates due to its optionality; i.e. aspectual se is said to be compatible but not necessary when a predicate shows the aspectual characteristics identified in such studies. These aspectual differences between the marked and the unmarked variant are then considered to be the cause of the meaning differences that sometimes arise between the two variants (see García Fernández [2015] for a detailed analysis of movement verbs in these terms). In this section, I will briefly consider some of the semantic differences that have been noted, looking at intransitive verbs of movement (Section 4.2.1) and stative verbs (Section 4.2.2).

\subsubsection{Movement verbs}

Intransitive movement verbs are frequently mentioned as examples of aspectual se. With these verbs, the RM is said to have such a semantic effect that the marked variant encodes "a sense of abandonment of the place of origin" (Sánchez López 2002: 118 , my translation). ${ }^{14}$ This is conveniently illustrated by the contrast between ir and irse, one of the few cases where the RM seems not to be optional and where its absence is actually infelicitous in some contexts. For instance, it is frequently noted that the non-reflexive form ir cannot take source complements (Babcock 1970; Bull 1952; García Fernández 2015; Martín Zorraquino 1979, 1993; Sánchez López 2002):

14 "[U]n sentido de abandono respecto del lugar de procedencia". 


El ${ }^{*}(\mathrm{se}) \quad v a$ de
he (REFL.3) goes from Barcelona.
'He leaves Barcelona.'
(Martín Zorraquino 1979: 111)

In De Miguel and Fernández Lagunilla's (2000) account, intransitive movement verbs such as ir(se) 'to go', bajar(se) 'to go down', subir(se) 'to go up' and venir(se) 'to come' have a complex event structure which consists of a transition between two achievement subevents because they encode a transition between two locations. Each of these subevents can itself be decomposed into two different phases (achievement + process / achievement + state, respectively). The addition of the RM "marks that the event culminates in a point followed by a change of state" (De Miguel and Fernández Lagunilla 2000: 28, my translation). ${ }^{15}$ This proposal can explain the sense of abandonment of the source location in (15). It can also explain the fact that the unmarked variant does allow a source complement with de when the preposition means 'from', see (16), but not when it means 'out of', as the COSER data show, since only in the latter reading is the change of state highlighted:

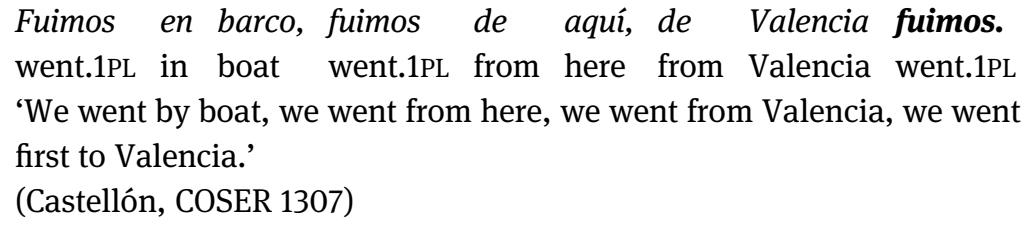

However, this aspectual conception of the RM cannot explain the asymmetry of the behavior of the RM with goal complements, where it is optional and often does not cause any meaning difference between both variants, as the (almost) minimal pairs in (17) and (18) show. As seen in Figure 1 above, those contexts are actually more frequent in discourse (see De Benito Moreno [2015] for more details on the similar behavior of other movement verbs).

$\begin{array}{llllllll}\text { a. Que } & \text { antes } & \text { nos } & \text { ibâmos } & \text { al } & \text { río, } & \text { ahora } & {[\ldots]} \\ \text { that } & \text { before } & \text { REFL.1PL } & \text { went.1PL } & \text { to.the } & \text { river } & \text { now } & \\ \text { lo } & \text { metemos } & a & l a & \text { bañera. } & & & \\ \text { it.ACC } & \text { put.in.1PL } & \text { to } & \text { the } & \text { bathtub } & & & \end{array}$
'Before, we used to go to the river, now [...] we put it in the bathtub.' (Navarra, COSER 3222)

15 “[...] señala que el evento culmina en un punto que desemboca en un cambio de estado.” 
b. Si no teníamos [...] ni aun agua pa beber, que if no had.1PL nor even water for drink.INF that teníamos que ir al río. had.1PL that go.INF to.the river 'We didn't even have [...] water to drink, we had to go to the river.' (Castellón, COSER 1307)

(18)

$\begin{array}{lllllll}\text { a. Se } & \text { salian } & \text { áhi } & \text { al } & \text { campo } & \text { habia } \\ \text { REFL.3 } & \text { went.out.3PL } & \text { there } & \text { to.the } & \text { field } & \text { and } & \text { had.3SG } \\ \text { un } & \text { terraplén } & \text { así } & m u & \text { grande } & \text { de } & \text { tierra. } \\ \text { a } & \text { embankment } & \text { so } & \text { very } & \text { big } & \text { of } & \text { soil }\end{array}$

'They [the children] used to go out into the field and there was a large earthen embankment.'

(Toledo, COSER 4206)

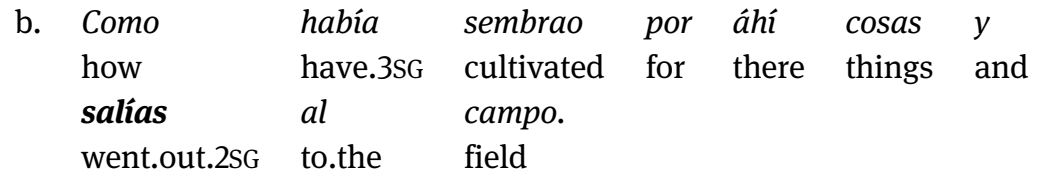

'Since there were different crops over there and you used to go out into the field.'

(Ciudad Real, COSER 1404)

This conception of the RM also fails to explain why the rejection of source complements with de 'out of' by the unmarked variant only appears with ir(se) but not with other movement verbs, with which it is optional, as the (almost) minimal pairs in (19) show (see also Cano 1981: 274):

(19) a. Cuando se salga ahora de aquí pa abajo, [...] when REFL.3 leave.3SG now from here for down a mano izquierda, sigan ustedes una ca[rretera] to hand left follow.3PL you.PL a road 'When you leave town now, going down, at the left, follow a road' (Huelva, COSER 2122)

b. Salíamos de aquí a las dos y media de mañana left.1PL from here at the two and half of morning 'We used to leave town at two thirty in the morning' (Huesca, COSER 2229) 


\subsubsection{Stative verbs}

As already mentioned above (Section 4.1.3), the acceptability of the RM with stative verbs such as saber(se) 'to know' is problematic for aspectual accounts. Accordingly, some authors have claimed that saberse is not a state, as opposed to saber (e.g. Sanz and Laka 2002; Zagona 1996). Other authors, however, accept that some states might take the RM, proposing that such states have a complex event structure. De Miguel and Fernández Lagunilla (2000), for instance, include states saber and estar 'to be' in their proposal of se as a marker of the culmination of an event by proposing that examples like (20) presuppose "the previous existence of an achievement that triggers the new state: the achievement of 'getting to know the lesson' or 'becoming quiet”' (De Miguel and Fernández Lagunilla 2000: 29, my translation). ${ }^{16}$

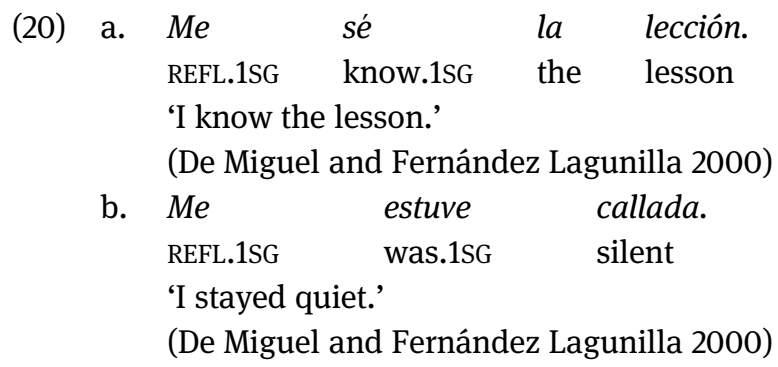

Nevertheless, this explanation is problematic, since such previous achievement is not coded in the event structure of the verb, as (21a) shows; in these contexts, saberse rejects temporal complements with en 'in', one of the syntactic tests used to identify delimited (i.e. telic) events such as achievements (De Miguel 1999). ${ }^{17}$ Moreover, saber might take temporal complements with en in contexts like (21c), which are said not to take the RM in aspectual approaches because it has a clausal complement. On the whole, this contradicts the idea that saberse has a "learn-like interpretation" and that "it has an eventive structure analogous to that of consumption verbs" (Campanini and Schäfer 2011: 12).

\footnotetext{
16 "[La] existencia previa de un logro que desencadena el nuevo estado: el logro de «pasar a saber la lección»".

17 MacDonald (2017) gives additional examples that support the claim that saberse is stative even if the RM is present; he does not defend a telic interpretation of those examples despite the presence of se.
} 
(21) a. ??Me he sabido la lección en un periquete. REFL.1SG have.1SG known the lesson in a tick 'I knew the lesson in a tick.'

b. $Y$ en un segundo supe que Juan habia llegado. and in a second knew.1SG that Juan had.3SG arrived 'And I realised in a second that Juan had arrived.'

Similarly, if this explanation (i.e. the possibility of interpreting a previous achievement that triggers the final state) were to be appropriate for the distribution of the RM with estar, we would expect an example such as (22a) to accept the RM since it implies a previous achievement (having discovered something) and an example such as (22b) to be impossible since it does not imply any change of state. We find, however, the opposite situation.

$\begin{array}{lllllll}\text { a. } & \text { iQué } & \text { contenta } & \text { (??te) } & \text { estás con lo que } \\ \text { what } & \text { happy } & \text { REFL.2SG } & \text { are.2SG with that that } \\ \text { has } & \text { descubierto! } & & & & & \\ & \\ \text { have.2SG } & \text { discovered } & & & & \end{array}$

'How happy you look with what you have discovered!'
b. A cualquiera que diga que me estoy con to anyone that say.1SG that REFL.1SG are.1SG with vosotras $y$ no haya hecho mi cama... you.2PL and no have.1SG done my bed 'If I were to tell someone that I'm here with you guys and that I have not yet made my bed...'

(El Barco de Ávila, Ávila, COSER 0607)

\subsubsection{Summary}

The data in this section reveal that relying on just a few examples where the RM might appear with some motion and stative verbs has led to generalizations that do not apply when an exhaustive sample of real speech is considered.

\subsection{Excluded predicates}

An important prediction of aspectual accounts is that the RM should be impossible with some predicates. In this section I will show that dialectal data contradict such predictions by focusing on entrar(se) 'to go in', llegar(se) 'to arrive', (des) aparecer(se) 'to (dis)appear' and vivir(se) 'to live'. 


\subsubsection{Entrar(se)}

De Miguel and Fernández Lagunilla (2000) note that entrarse 'to go in, to enter' is not expected in their account of culminative se because it conveys an accomplishment not followed by a final state. They do, however, acknowledge that entrarse is possible in some varieties and, despite the fact that they explicitly decide to disregard those varieties in their study, they also claim that the meaning of entrarse is closer to meterse 'to get in' than to entrar, which would justify the accommodation of entrarse in their account. ${ }^{18}$ The COSER data, due to their diverse dialectal composition, document several examples of entrarse (15 in total), all of which are perfectly replaceable by entrar (see De Benito Moreno 2015). Moreover, in many of them the replacement by meterse would be either marked or inappropriate ${ }^{19}$ :

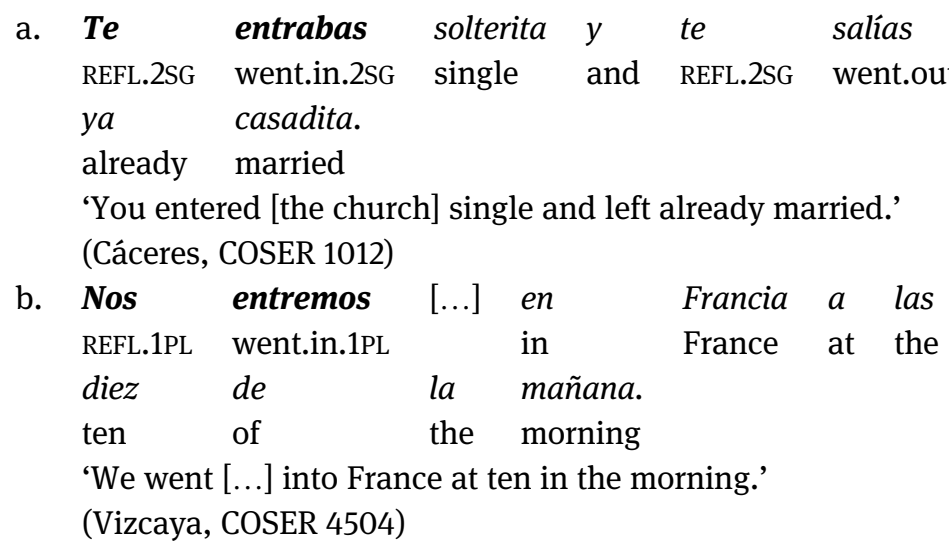

\subsubsection{Llegar(se)}

Sanz and Laka (2002) consider the attachment of the RM to llegar 'to arrive' to be impossible. This is a direct result of their claim that the RM is an overt marker of accomplishments and that all unaccusative verbs (except for morir 'to die' and caer 'to fall') encode achievements. Similarly, De Miguel and Fernández Lagunilla

18 Aaron (2003) also attests entrarse (albeit rarely) in speakers form New Mexico. So does García Fernández (2015) when looking for examples on Google. Note that his analysis does not preclude the possibility of finding entrarse.

19 These examples of entrarse do not seem to be due to the use of entrar as a transitive verb (i.e. 'to bring in'), since the COSER data shows that reflexive entrarse and causative entrar appear in only partially overlapping varieties (see De Benito Moreno [2015] for a more detailed analysis of these data). 
(2000) believe that the absence of a final result state prevents llegar from taking the RM, despite the fact that it has a culmination phase. Again, these authors note that llegarse is possible in some varieties and point out that llegarse has a meaning closer to acercarse 'to get closer', which would allow for the inclusion of this variant in their account. However, the COSER examples show that this change of meaning does not adequately explain the distribution of the RM with llegar - all 6 examples of llegarse could be replaced by unmarked llegar, but the replacement by acercarse would be marked or inappropriate in most cases (see also De Benito Moreno 2015):

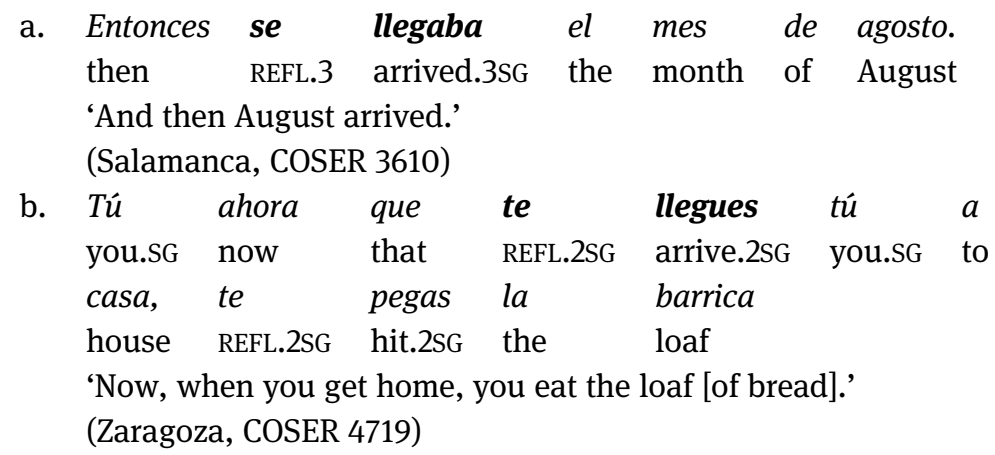

\subsection{3 (Des)aparecer(se)}

The form aparecerse 'to appear' is explicitly rejected by Sanz and Laka (2002) on the same grounds as llegarse - it is an unaccusative verb that encodes an achievement. Aparecerse, however, is the default variant of the verb when it refers to supernatural subjects such as ghosts in Standard Spanish (Seco et al. 1999), where it is still an unaccusative achievement. Moreover, the responses to a visual questionnaire conducted as an additional source of information to the COSER interviews (De Benito Moreno 2015) show that the forms aparecerse and desaparecerse 'to disappear' can show the same meaning as their unmarked counterparts, possible in some varieties of Spanish. They alternate with the unmarked form as shown in (25):

Ha desaparecío. $\mathrm{Ha}$ quitao... S'-ha desaparecío. has.3SG disappeared have.3SG taken.away REFL.3-have.3SG disappeared 'It [the picture on the screen]'s disappeared. They've taken away... It has disappeared.'

(Huelva, QT 012) 


\subsubsection{Vivir(se)}

The attachment of the RM to vivir 'to live' is unexpected in several aspectual accounts for it is atelic (Sanz and Laka 2002) and unergative, that is it has no internal argument (Rigau 1994). However, vivirse (with the meaning to live somewhere') is also found dialectally in Peninsular Spanish:

$\begin{array}{lllllll}\text { Digo: } & \text { "Mire”, } & {[\ldots]} & \text { mis } & \text { padres, } & \text { yo me } & \text { vivía más } \\ \text { say.1SG look.IMP } & \text { my } & \text { parents } & \text { I } & \text { REFL.1SG lived more } \\ \text { abajo, pero } & \text { yo } & \text { aquí subí. } & & & \\ \text { down but } & \text { I } & \text { here } & \text { went.up.1SG } & & \\ \text { 'I say: "Look", [...] my parents, I lived in the lower part of town, but I came } \\ \text { up here.' } \\ \text { (Huércanos, La Rioja, COSER 2506) }\end{array}$

\subsubsection{Summary}

In this section, I have shown that aspectual accounts of the RM cannot accommodate some variation facts of the distribution of the RM. Since aspectual se is deemed to be a facultative marker, it is not unexpected that it is more productive in some varieties than in others. However, we would expect such variation to go in a direction compatible with the alleged aspectual function of the RM, otherwise the behavior of the RM in these varieties (which differs from Standard Spanish only in the behavior of the RM with some verbs, but not all of them) would require a different explanation. However, the data show reflexive verbs that do not fit within the aspectual interpretation of the RM.

This discrepancy could be explained if all the exceptions stemmed from a single focus, since it could be argued that they belong to a dialect with a different (and broader) interpretation of the function of the RM. However, we find no such geographical pattern. On the contrary, each of these verbs seem to show a unique spatial distribution. These distributions only sometimes partially overlap (see Figure 3). Accordingly, we would need a new interpretation of the RM in each dialect that could account for their respective "exceptions".

\subsection{Ignored predicates}

Most authors who provide an aspectual account of the RM fail to explicitly delimit the members of this reflexive class. According to one of the few clear definitions, 
Reflexive intransitive verbs excluded by aspectual accounts
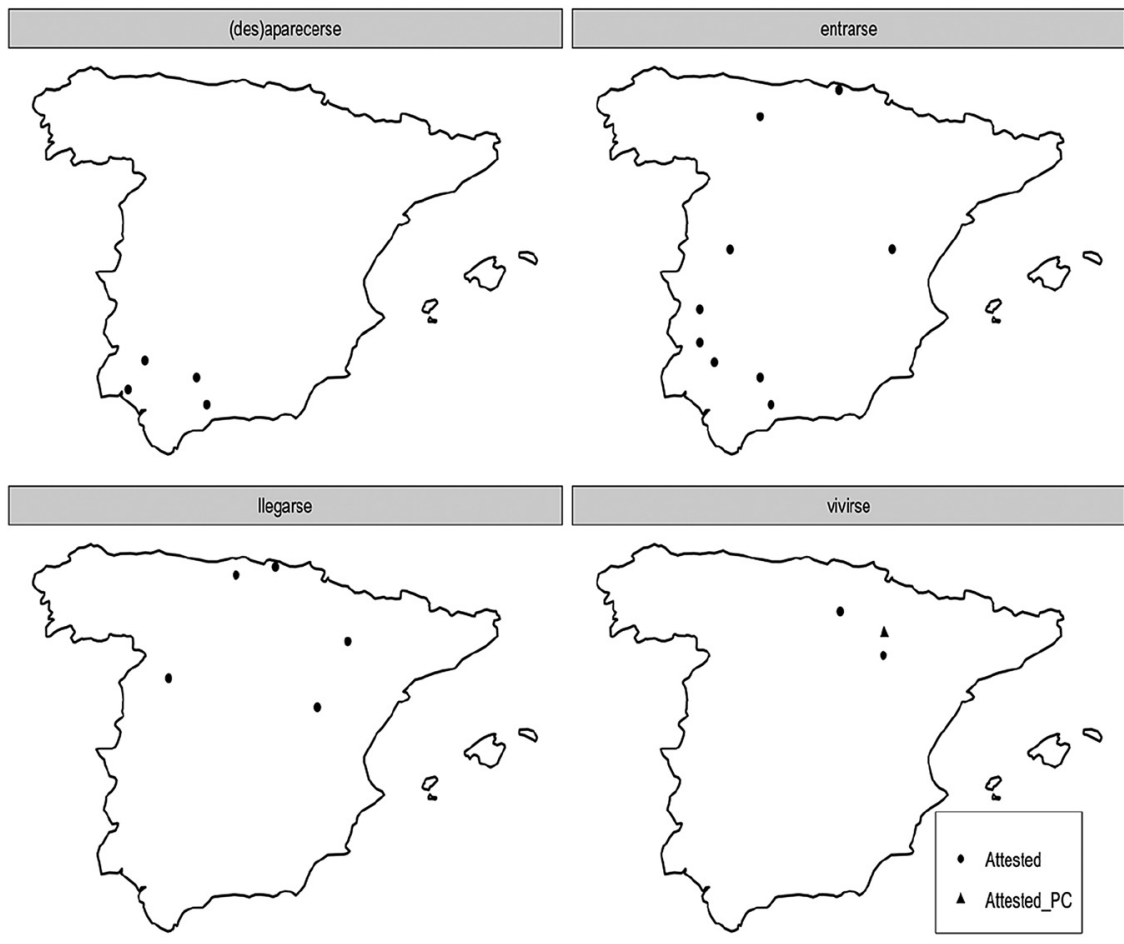

Figure 3: Some reflexive intransitive verbs excluded by aspectual accounts. ${ }^{20}$

namely that of Sánchez López (2002, quoted in Section 2), it aims to include all reflexive verbs that show no change in their argument structure or in the interpretation of its arguments. The exhaustive analysis of a large corpus (such as the one conducted by De Benito Moreno 2015, in revision) provides a large number of facultative reflexive verbs that have not been addressed in accounts based on introspection. One interesting example is that of corporal processes such as mear(se) 'to piss', cagar(se) 'to shit', hacer(se) pis 'to pee', hacerse caca 'to poop/ pooh'. Introspectively, the presence of the RM seems to be related to the lack of control of the subject, and it has an effect on the interpretation of imperfective tenses, which in the reflexive form allow an inceptive reading not possible in the unmarked form:

20 The COSER data attests vivirse only in two locations. However, Ekaitz Santazilia (p.c,) also finds it in the town of Ribaforada (Navarra), supporting the spatial pattern drawn by the COSER data. Ribaforada is marked in Figure 3 as 'Attested_PC' (attested, p.c.). 

a. Estoy \{cagando/ meando\} am shitting pissing 'I'm taking a \{shit / piss\}'
b. Me estoy \{cagando/ meando\} REFL.1SG am shitting pissing 'I feel the need to take a \{shit / piss\}' - 'I'm taking a \{shit / piss\}'

This behavior is reminiscent of the verb marear(se) 'to get dizzy', which De Miguel and Fernández Lagunilla (2000) classify as an inceptive achievement. According to these authors, only inceptive achievements whose culmination point is followed by a state (marear(se), caer(se) 'to fall down') allow the RM, but the culmination point of mear(se), cagar(se) and hacer(se) pis 'to pee', hacerse caca 'to poop/pooh' seems to be followed by an activity, and should then be unmarked according to this account (like florecer 'to bloom').

This example shows that, by relying on introspective judgements, supposedly comprehensive accounts have failed to include potentially interesting cases or to develop the criteria to exclude them. Other similar examples could be cited (for instance, reflexive symmetrical intransitive verbs such as pelear(se)), see De Benito Moreno (2015, in revision).

\section{Discussion and conclusion}

In this paper, I have shown that aspectual accounts of the RM based on introspective data describe and predict stricter contrasts between the marked and unmarked variants than as shown by corpus data: 1) the requirement of a delimited DO, one of the strongest contrasts found in the literature, does not apply to all transitive verbs but only to a few, which have received most attention in the literature; 2) the semantic implications attributed to the aspectual meaning of the RM fall short of general adequacy and do not apply to a large part of the data, and 3) several reflexive verbs which have been claimed to be impossible due to the alleged aspectual function of the RM are found in non-standard dialects that do not differ in other crucial aspects from the varieties typically taken into consideration. That is, aspectual analyses of the RM in Spanish fail to account for a large part of the data as also shown by the existence of reflexive facultative uses that have thus far been ignored in the literature. It seems to me that this situation is symptomatic of one of the crucial flaws in most accounts of aspectual se: this category is almost never defined beforehand; rather, it is simply illustrated by means of a few examples. One exception is Sánchez López (2002), whose definition was given in 
Section 2, and has been followed here. Yet, as described above, aspectual approaches fail to account for all the data that fit this definition.

In addition, I have argued that the fact that large parts of the data have been disregarded and thus unaccounted for has to do with the methods used in the study of facultative uses of the RM. Aspectual accounts typically rely on introspective judgements and carefully constructed examples that seek to maximize the semantic contrast between marked and unmarked forms. As discussed in Section 2, the use of such clear examples sets the perfect scenario for proposing a clear-cut grammatical function of the RM, which in turn has inadvertently contributed to a blindness to data that do not easily fit such accounts.

While in this paper I have focused on aspectual accounts of the RM because they are the most numerous, it should be noted that other accounts of facultative uses of the RM based on introspective judgements show similar problems. For instance, Maldonado (2000) proposes that the RM in transitive verbs indicates the incorporation of the object in the subject dominion, showing maximal object exploitation and highlighting the agent's involvement. Accordingly, he proposes the contrasts in (28) below, regarding the combination of the RM and the intensifier de una sentada 'in one sitting'. While the intuitions on which these contrasts are based might be true, a quick search on social media sites show that they are too strong as shown in (29). ${ }^{21}$ This suggests that introspection is not an appropriate method for the study of these uses because it leads to the overrepresentation of some contexts and the overstatement of some contrasts. As Willems (2012: 678) puts it: "[N]ot only does the variability of language use (in different contexts, by different speakers using different registers, etc.) transcend the "competence" of individual speakers, corpus-based evidence also shows that discourse is much more varied and multifaceted than might be supposed on the basis of an individual's linguistic intuition”.

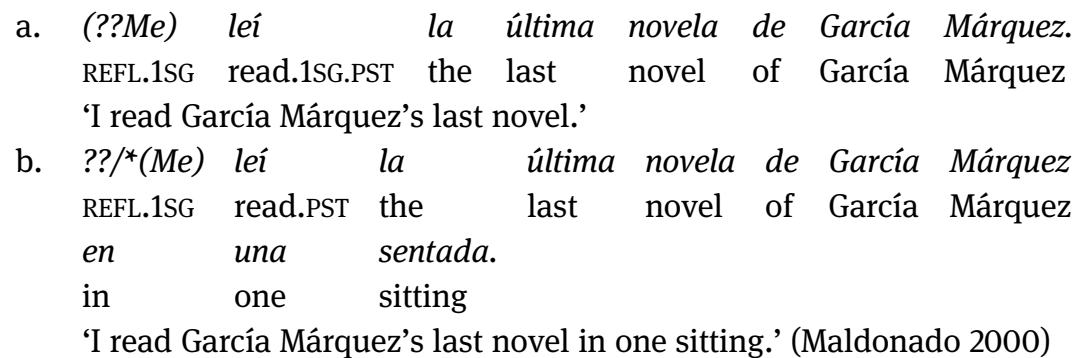

21 Mexican examples have been chosen here because this is also Maldonado's variety. 


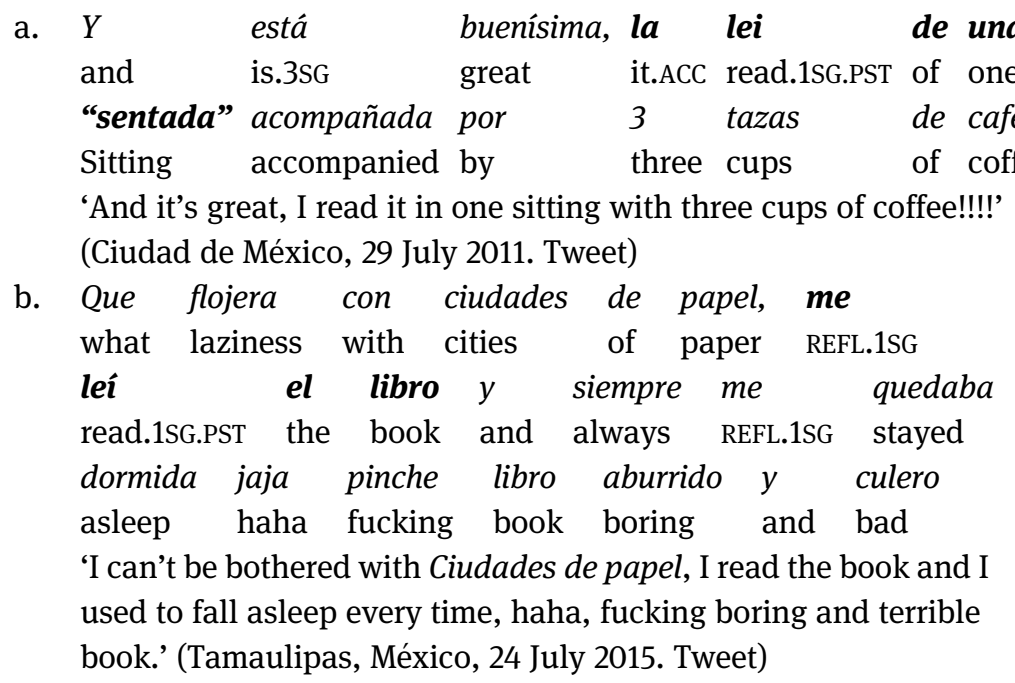

Introspection, it seems, has effectively slowed down our understanding of these uses since progress has been made through a slow drip of new examples. As noted above (Section 4.1.1), it was not until 2011 that examples of reflexive consumption verbs with bare direct objects were considered (and these are sometimes still ignored, see MacDonald [2017]). Moreover, introspective judgments are especially inadvisable in this case, for the presence of the RM is subject to dialectal, social and stylistic variation and thus shows a distribution that is difficult to access through the researcher's individual intuition. This might explain the discrepancies regarding the grammaticality of the examples sometimes found in the literature.

As described above, a more recent tendency can be found in the literature with a number of variationist accounts that confirm that aspectual analyses based on observations are not applicable to all the contexts of real speech in which the RM is found (Aaron 2003, 2004; Aaron and Torres Cacullos 2005; De la Mora 2011; Merino Hernández 2019; Torres Cacoullos and Schwenter 2008; Rivas 2011). These usagebased approaches show some clear advantages since they include a larger number of contexts and do not rely on the individual judgements of the researcher ${ }^{22}$ First, they have been able to show that the contrasts proposed in the literature are not as clear-cut as it seems. For instance, Aaron (2003) finds that irse only means

22 One of the most problematic characteristics of individual judgements is that they are not falsifiable. In Aaron and Torres Cacoullos' (2005: 614) words: “One analyst's judgements are susceptible to another's disputing, with no scientific advances achieved”. 
'to leave' in 29\% of the cases she analyses. Similarly, both Rivas (2011) and De la Mora (2011) find examples of marked consumption verbs with bare plural objects. Second, they have shown that a particular "construction effect" (Torres Cacoullos and Schwenter 2008: 1471) might be present in the distribution of the RM - Torres Cacoullos and Schwenter (2008) find that subirse 'to go up' and bajarse 'to go down' most often appear in the construction 'enter/exit a vehicle'. Last and most importantly, variationist studies have shown that the distribution of the RM with these verbs is not determined by a single factor but that it can be affected by a number of linguistic and even extralinguistic factors, such as dialect or register.

However, they are not free of the influence of accounts based on introspection, something which is clearly seen in the fact that they have focused on a small number of verbs, all of these discussed in the literature previously (consumption verbs, a few movement verbs - ir(se), salir(se), subir(se) and bajar(se) - and morir(se)). That is, a large number of verbs that show the optional presence of the $\mathrm{RM}$ are also disregarded in these accounts. That this bias is due to the influence of previous literature is quite clear in Aaron's (2003) work, who explains the focus of her study as follows: "[t]hough the study included a total of eight verbs, two verbs in particular offer insight into the nature of clitic use variation: $\operatorname{ir}(s e)$ and salir(se), which will be the focus of this paper" (Aaron 2003: 125). The insight they offer seems to be directly related with the 'energetic se' reading proposed by Maldonado (1989, 1999), which Aaron wants to empirically check in her work since her sample contains verbs that are more represented in global quantitative terms (there are 253 occurrences of venir(se) 'to come', but only 109 of salir(se) 'to go out') as well as regarding the number of marked occurrences (41 of quedarse 'to stay' and 27 of venirse, but only 19 of salirse).

From a theoretical perspective, these variationist studies are quite heterogeneous in that some try to offer support for only one of the accounts previously proposed in the literature while others try to conbine several of those accounts and look for evidence in favor of the effect of all of them. This is precisely one of the most valuable contributions of these studies since they try to find empirical evidence that supports the different proposals about the function of the RM. Thus, they not only consider proposals of an aspectual se but also Maldonado's (1989, 1999, 2000) proposals of an energetic se, of the role of counter-expectation and agent's involvement, and Clements' (2006) proposal that the RM is affected more generally by the transitivity of the clause. Another important contribution of variationist studies has been to investigate the role of pragmatic factors such as foregrounding, topicality and speaker's involvement in the distribution of the RM and to find ways of operationalizing such factors.

However, such heterogeneity complicates the task of combining their findings. First, these studies not always take the same factors into account, even when considering similar verbs and theories. One clear example to illustrate this: although Aaron (2003) - for salir(se) 'to go out' and ir(se) 'to go' - and Torres 
Cacoullos and Schwenter (2008) -for subir(se) 'to go up' and bajar(se) 'to go down' - consider clause type in their analyses as a proxy for pragmatic parameters, Aaron and Torres Cacoullos (2005) - for salir(se) 'to go out' - do not. Both De la Mora (2011) and Rivas (2011) consider this parameter (both for consumption verbs) but they distinguish different levels - while De la Mora opposes declarative to interrogative clauses, Rivas opposes main to other clauses.

Second, the results of factors that are similar are not always coherent with each other. For instance, while Aaron (2003) finds that main clauses favor significantly the presence of the RM, no such effect is found by Torres Cacoullos and Schwenter (2008). Sometimes the results are even contradictory. A point in case is animacy of the subject with consumption verbs. Rivas (2011) finds that most of his marked examples have human subjects and, thus, excludes this factor as not being part of the variable context. However, De la Mora (2011) does include the factor and finds that non-human subjects significantly favor the presence of the RM - a result that directly contradicts Rivas's (2011).

Third, because several proposals about the function of the RM are being tested and because they predict different outcomes, almost every possible result can be used as evidence for one of these proposals. Take, for instance, the interpretation of the results regarding the animacy of the subject with consumption verbs that I just mentioned. Both authors include this factor in order to test if the RM is associated with high transitivity. Rivas's (2011) results support this theory, while De la Mora's (2011) are in contradiction with it. However, because De la Mora is testing the theory that the RM might mark counter-expectation as well, she integrates her result as supporting evidence for this theory. Methodologically, this is problematic. A similar methodological issue arises through the fact that often multiple factors are investigated in support of a given theory but only significant results are discussed, without considering what the lack of an observable effect in the some of the factors included implies for the predictions of each theory.

Last, general patterns are also hard to find because the results often highlight the fact that the presence of the RM seems to be affected by highly idiosyncratic factors. As said above, Torres Cacoullos and Schwenter (2008) note that the most important factor determining the presence of the RM is a construction effect. Moreover, almost every study that addresses more than one verb finds important differences among them regarding the frequency of the RM - verb lexeme is the most relevant explanatory factor for the presence of the RM in the two studies that analyse consumption verbs (De la Mora 2011; Rivas 2011) and the second most relevant in Aaron's (2003) study. A comparison of all these variationist studies also show important differences in the frequency of the RM with each individual verb.

In my opinion, variationist studies are the most promising method to provide a good understanding of the facultative uses of the RM because they considerably 
enlarge the sample of contexts under consideration. But we must also enlarge the sample of verbs that participate in the alternation. Thus, I argue in favor of turning to exhaustively analyzed corpus data for the study of these uses (see De Benito Moreno 2015, in revision). Such an analysis shows that, while the RM seems to be associated with similar meanings when attached to different verbs (García Fernández 2015), these meanings are quite dependent on the semantics of the verb to which it attaches (De Benito Moreno 2015, in revision). This in turn raises the question of how syntactically determined (as opposed to lexically determined) the presence of the RM is. Moreover, it casts doubt on the assumption that a single function underlies the behavior of the RM in these cases, an assumption adopted by most of the authors that have addressed these facultative uses. As I argue elsewhere (De Benito Moreno 2015, in revision), I believe that an account of facultative uses of the RM must take into consideration other functions of the RM (reflexive, reciprocal, anticausative, etc.), which seem to have served as the source of an analogy for the extension of the RM to other verbs where it has no effect on the valency of these verbs. Such an analogy is syntagmatic and paradigmatic (see Fischer 2008 and De Smet 2012) and is not based on a single parameter but on several, from which the most relevant are the semantic class of the verb, the nature of the subject, and the presence of an external cause.

\section{References}

Aaron, Jessi Elana. 2003. Me salí a caminar: Pronominal constructions with intransitive motion verbs in northern New Mexican Spanish. In Lotfi Sayahi (ed.), Selected proceedings of the First Workshop on Spanish Sociolinguistics, 123-133. Somerville, MA: Cascadilla Proceedings Project.

Aaron, Jessi Elana. 2004. The gendered use of salirse in Mexican Spanish: Si me salía yo con las amigas, se enojaba. Language in Society 33(4). 585-607.

Aaron, Jessi Elana \& Rena Torres Cacoullos. 2005. Quantitative measures of subjectification: A variationist study of Spanish salir(se). Cognitive Linguistics 16(4). 607-633.

Alcina Franch, Juan \& José Manuel Blecua. 1975. Gramática española. Barcelona: Ariel.

Anvari, Amir, Mora Maldonado \& Andrés Soria Ruiz. 2019. The puzzle of reflexive belief construction in Spanish. In M. Teresa Espinal, Elena Castroviejo, Manuel Leonetti, Louise McNally \& Cristina Real-Puigdollers (eds.), Proceedings of Sinn und Bedeutung 23, 57-74. Barcelona: Universidad Autònoma de Barcelona.

Armstrong, Grant. 2013. Agentive reflexive clitics and transitive se constructions in Spanish. Borealis 2(2). 81-128.

Babcock, Sandra S. 1970. The syntax of Spanish reflexive verbs. The Hague: Mouton. Basilico, David. 2010. The se clitic and its relationship to paths. Probus 22. 271-302. Bull, William E. 1952. The intransitive reflexive: 'ir' vs. 'irse'. The Modern Language Journal 36(8). 382-386. 
Campanini, Cinzia \& Florian Schäfer. 2011. Optional se-constructions in Romance: Syntactic encoding of conceptual information. Paper presented at Generative Linguistics in the Old World 34, University of Vienna. http://ifla.uni-stuttgart.de/institut/mitarbeiter/florian/ papers/glow34.pdf (accessed 26 February 2017).

Cano, Rafael. 1981. Estructuras sintácticas transitivas en el español actual. Madrid: Gredos.

Cartagena, Nelson. 1972. Sentido y estructura de las construcciones pronominales en español. Concepción: Universidad de Concepción.

Cidrás Escáneo, Francisco A. 1991. As construccións pronominais en galego. Proposta de clasificación e caracterización. In Mercedes Brea \& Francisco Fernández Rei (eds.), Homenaxe ó profesor Constantino García, 101-125. Santiago de Compostela: Universidade de Santiago de Compostela.

Clements, J. Clancy. 2006. Transitivity and Spanish non-anaphoric se. In J. Clancy Clements \& Jiyoung Yoon (eds.), Functional approaches to Spanish syntax, 236-264. London: Palgrave Macmillan.

Cornips, Leonie \& Aafke Hulk. 1996. Ergative reflexives in Heerlen Dutch and French. Studia Linguistica 50(1). 1-21.

COSER = Fernández-Ordóñez, Inés. 2005. COSER. Corpus Oral y Sonoro del Español Rural. Available at: http://www.corpusrural.es/.

D’Andrés, Ramón. 1994. Los pronomes reflexivos átonos n'asturianu. Lletres Asturianes 51. 7-22.

De Benito Moreno, Carlota. 2015. Constructions with se: $A$ variationist and dialectal perspective. Madrid: Universidad Autónoma de Madrid dissertation.

De Benito Moreno, Carlota. In revision. The middle voice in Ibero-Romance: A variationist and dialectal account.

De la Mora, Juliana. 2011. A quantitative approach to variable se-marking in Spanish ingestive verbs. Ohio: The Ohio State University dissertation.

De Miguel, Elena. 1999. El aspecto léxico. In Ignacio Bosque \& Violeta Demonte (eds.), Gramática descriptiva de la lengua española, vol. 2, 2977-3060. Madrid: Espasa.

De Miguel, Elena \& Marina Fernández Lagunilla. 2000. El operador aspectual se. Revista Española de Lingüística 30(1). 13-43.

De Smet, Hendrik. 2012. The course of actualization. Language 88. 601-633.

Di Tullio, Ángela. 2012. La construcción de la lectura agentiva del se no argumental. In Valeriano Bellosta von Colber \& Marco García García (eds.), Aspectualidad - Transitividad Referencialidad. Las lenguas románicas en contraste, 69-85. Frankfurt: Peter Lang.

Dowty, David. 1979. Word meaning and Montague grammar. Dordrecht: Reidel.

Fernández Ramírez, Salvador. 1986. Gramática española. 4. El verbo y la oración. Madrid: Arco/ Libros.

Fischer, Olga. 2008. On analogy as the motivation for grammaticalization. Studies in Language 32(2). 336-382.

García Fernández, Luis. 2015. Some reflections on verbs with clitic increase: Verbs of motion. In Elisa Barrajón López, José Luis Cifuentes Honrubia \& Susana Rodríguez Rosique (eds.), Verb classes and aspects, 264-287. Amsterdam: John Benjamins.

Gómez Torrego, Leonardo. 1992. Valores gramaticales de se. Madrid: Arco/Libros.

Itkonen, Esa. 2005. Concerning the synthesis between intuition-based study of norms and observation-based study of corpora. SKY Journal of Linguistics 18. 357-377. http://www. linguistics.fi/julkaisut/SKY2005/Itkonen.pdf.

Kahneman, Daniel. 2011. Thinking, fast and slow. London: Penguin. 
Kailuweit, Rolf. 2011. Romance anticausatives: A constructionist RRG approach. In Wataru Nakamura (ed.), New perspectives in role and reference grammar, 104-133. Newcastle upon Tyne: Cambridge Scholars Publishing.

Kemmer, Suzanne. 1993. The middle voice (Typological Studies in Language 23). Amsterdam: John Benjamins. https://doi.org/10.1075/tsl.23.

MacDonald, Jonathan E. 2017. Spanish aspectual se as an indirect object reflexive: The import of atelicity, bare nouns, and leísta PCC repairs. Probus 29(1). 73-117.

Maldonado, Ricardo. 1989. Se gramaticalizó: A diachronic account of energetic reflexives in Spanish. In Robert J. Carlson, Scott C. DeLancey, Spike Gildea, Doris Payne \& Anju Saxena (eds.), Proceedings of the Fourth Meeting of the Pacific Linguistics Conference, 339-360. Eugene: University of Oregon, Dept. of Linguistics.

Maldonado, Ricardo. 1999. A media voz. Mexico: Universidad Nacional Autónoma de México.

Maldonado, Ricardo. 2000. Conceptual distance and transitivity increase in Spanish reflexives. In Zygmunt Frajzyngier \& Traci Walker (eds.), Reflexives: Forms and functions, 153-185. Amsterdam: John Benjamins.

Martín Zorraquino, María Antonia. 1979. Las construcciones pronominales: paradigma y desviaciones. Madrid: Gredos.

Martín Zorraquino, María Antonia. 1993. 'Ir' e 'irse' en el Cantar de Mío Cid. Aragón en la Edad Media 10-11. 575-578.

McCready, Eric \& Chiyo Nishida. 2008. Reflexive intransitives in Spanish and event semantics. In Johannes Dölling, Tatjana Heyde-Zybatow \& Martin Schäfer (eds.), Event structures in linguistic form and interpretation, 223-243. Berlin: Walter de Gruyter.

Merino Hernández, Laura Margarita. 2019. Condicionamiento pragmático y semántico del marcador de voz media se en el verbo morirse. Cuadernos de Lingüística de El Colegio de México 6(1). e81.

Nedjalkov, Vladimir P. (ed.). 2007. Reciprocal constructions (Typological Studies in Language 71), vol. 5. Amsterdam: John Benjamins.

Nisbett, Richard E. \& Eugene Borgida. 1975. Attribution and the psychology of prediction. Journal of Personality and Social Psychology 32. 932-943.

Nishida, Chiyo. 1994. The Spanish reflexive clitic se as an aspectual class marker. Linguistics 32. 425-458.

Otero, Carlos Peregrín. 2002. Facetas de se. In Cristina Sánchez López (ed.), Las construcciones con se, 165-206. Madrid: Visor.

Rigau, Gemma. 1994. Les propietats dels verbs pronominals. Els Marges 50. 29-39. https://www. raco.cat/index.php/Marges/article/view/111162.

Rivas, Javier. 2011. 'Como no me trago el humo...' A corpus-based approach to aspectual se. Studies in Hispanic and Lusophone Linguistics 4(2). 379-416.

Romero Pascual, Cristina \& Ismael Iván Teomiro García. 2012. La relación entre estructura eventiva y papeles temáticos: el se aspectual del español. Revista de Filología Románica 29(2). 233-243.

Sánchez López, Cristina. 2002. Las construcciones con se. Estado de la cuestión. In Cristina Sánchez López (ed.), Las construcciones con se, 13-163. Madrid: Visor.

Sanz, Montserrat \& Itziar Laka. 2002. Oraciones transitivas con se. El modo de acción en la sintaxis. In Cristina Sánchez López (ed.), Las construcciones con se, 309-391. Madrid: Visor.

Seco, Manuel, Olimpia Andrés \& Gabino Ramos. 1999. Diccionario del español actual. Madrid: Aguilar.

Siewierska, Anna. 1984. The passive: A comparative linguistic analysis. London: Croom Helm. 
Teomiro García, Ismael I. 2013. Low applicatives and optional se in Spanish non-anticausative intransitive verbs. Revista de Lingüística y Lenguas Aplicadas 8. 140-153.

Torres Cacoullos, Rena \& Scott A. Schwenter. 2008. Constructions and pragmatics: Variable middle marking in Spanish subir(se) 'go up' and bajar(se) 'go down'. Journal of Pragmatics 40. $1455-1477$.

Tversky, Amos \& Daniel Kahneman. 1971. Belief in the law of small numbers. Psychological Bulletin 76(2). 105-110.

Willems, Klaas. 2012. Intuition, introspection and observation in linguistic inquiry. Language Sciences 34. 665-681.

Zagona, Karen. 1996. Compositionality of aspect: Evidence from Spanish aspectual se. In Claudia Parodi (ed.), Aspects of Romance linguistics, 475-488. Washington, DC: Georgetown University Press. 